\title{
Tatag De Penyawo: Perenungan Atas Identitas Kesukuan
}

\author{
M. Heni Winahyuningsih dan Usman Najrid Maulana ${ }^{1}$ \\ Jurusan Tari, Fakultas Seni Pertunjukan, Institut Seni Indonesia Yogyakarta
}

\begin{abstract}
ABSTRAK
Tatag de Penyawo adalah sebuah koreografi kelompok yang ditampilkan oleh 9 orang penari laki-laki. Karya ini lahir dari hasil perenungan penata tari yang gelisah dengan identitas kesukuan. Paham animisme merupakan citra yang melekat pada kehidupan masyarakat suku Dayak, yang sebagaian besar dari kehidupan mereka sangat dekat dengan roh-roh leluhur, hal-hal supranatural, dan keyakinan yang kuat terhadap gejala-gejala alam dan tingkah laku binatang. Kepercayaan leluhur yang disebut kaharingan memberi ruang yang luas untuk melakukan berbagai upacara adat dengan penampilan berbagai kesenian. Ketika agama-agama besar mulai dikenal dan dianut oleh sebagian besar masyarakat Dayak, tradisi upacara adat mulai ditinggalkan, dan keberadaan kesenian pun mulai terancam. Ada sebagaian sub suku Dayak yang ketika mulai memeluk agama baru tidak lagi mengakui sebagai bagian dari Suku Dayak, tetapi menyebut suku Melayu sebagai identitas kesukuannya. Hal inilah yang dialami oleh penata tari. Dia dilahirkan oleh seorang perempuan Suku Tidung yang memeluk agama Islam, sehingga harus menanggalkan kedayakannya, dan menjadi warga suku Melayu. Panggilan hati untuk terus menghormati tradisi kesukuan leluhurnya melalui aktivitas kesenian membuatnya tidak ingin kehilangan identitas sebagai orang Dayak yang beragama Islam. Melalui karya tari Tatag De Penyawo ini ia ingin merefleksikan identitas kesukuannya, dengan mengeksplorasi pola-pola gerak yang terdapat dalam tari tradisi Dayak, Hudoq Kita`.
\end{abstract}

Kata kunci: Dayak, identitas suku, Hudoq Kita’

\section{ABSTRACT}

Tatag De Penyawo : The contemplation of ethnic identity. Tatag de Penyawo is a group of coreography performed by nine male performers. This piece was born from the coreographer's contemplation who worries about the ethnic identity. Animism is an image which attaches to the social life of Dayak. Tribe, which is very close to their ancestor's spirit, supernatural things, and strong belief to the natural phenomena and animal behavior. The ancestral belief, which is called Kaharingan, gives a lot of opportunities to perform traditional ceremonies featuring a variety of arts. When the major religions firstly known and believed by Dayak people, the traditional ceremony had been left behind. The situation endangered the existence of arts. When some people of Dayak tribe started to follow the new religion, they claimed themselves as Melayu Tribe for their ethnic identity instead of Dayak Tribe. The situation had also affected the choreographer's life. He was born by a Muslim Dayak lady, and consequently, the Dayak culture has been abandoned since he becomes a part of Melayu Tribe. The coreographer's desire to honor his ancestor tradition with arts activities leads him to maintain his identity as a part of Dayak Tribe who follows Islam. By this piece of arts, Tatag De Penyawo, he wants to reflect his ethnical identity by exploring the movement pattern in traditional dance of Dayak, Hudoq Kita:

Keywords: Dayak dance, Ethnic identity, Hudoq Kita

\section{Pendahuluan}

Tatag De Penyawo adalah sebuah karya tari kontemporer dengan latar belakang etnis Suku Dayak di Kalimantan Timur. Karya ini merupakan ekspresi kegelisahan penata tarinya yang berada dalam keraguan identitas. Akankah dia menyebut dirinya suku Melayu karena ia muslim, ataukah menyebut Dayak karena darah yang mengalir di tubuhnya adalah tetesan leluhur yang mewariskan naluri kedayakan kepadanya.

Dayak atau Daya (ejaan lama: Dajak atau Dyak) adalah nama yang oleh penduduk pesisir pulau Kalimantan diberikan kepada masyarakat pedalaman yang mendiami pulau itu yang mencakup negara Brunei Darussalam, sebagian wilayah negara Malaysia yang terdiri dari Sabah dan Sarawak, serta negara Indonesia yang terdiri dari provinsi Kalimantan Barat, Kalimantan Timur, Kalimantan Tengah, Kalimantan Selatan, dan Kalimantan Utara.

Menurut Yekti Maunati, masyarakat Dayak Kalimantan merupakan suku bangsa yang heterogen, yang terdiri dari kurang lebih 405 sub suku kecil dari 6 rumpun yaitu rumpun Klemantan, Iban, Apo Kayaan, Murut, Ot Danum-Ngaju, dan Punan, yang masing-masing memiliki sejumlah kesamaan yang signifikan sehingga masih memungkinkan untuk mengkaji kebudayaan Dayak sebagai satu kesatuan, terkecuali suku

1 Alamat korespondensi: Jurusan Tari ISI Yogyakarta Jalan Parangtritis Km 6.5. Sewon, Bantul, Yogyakarta. E-mail: heniwie@ yahoo.com 
Punan yang lebih nomadik. Kesamaan-kesamaan yang dimaksudkan meliputi kesamaan hukum adat dan pantangan, upacara kelahiran anak, perkawinan, kematian, ritual pengobatan, tradisi mengayau (berburu kepala), serta ritual panen raya. Penyebab keberagaman sub-sukunya adalah persebaran populasi dari satu generasi ke generasi berikutnya melalui persebaran cabang anak sungai yang seiring berjalannya waktu mendiami dan berkembang di wilayah tertentu dan membentuk pola kebudayaan baru berdasarkan kebudayaan lama leluhurnya (Maunati, 2006: 61).

Paham animisme merupakan dominasi terkuat pada citra kehidupan masyarakat suku Dayak, yang sebagaian besar kehidupan mereka sangat dekat dengan roh-roh leluhur, hal-hal supranatural dan keyakinan yang kuat terhadap gejala-gejala alam dan tingkah laku hewan (dalam hal ini bunyi-bunyian dan arah terbang burung Enggang/Rhinoceros Hornbill yang diyakini sebagai roh tertinggi dalam hubungannya dengan alam atas) sebagai pertanda menyangkut kelangsungan hidup mereka. Kepercayaan yang dianut masyarakat Dayak secara turun-temurun dari nenek moyang mereka disebut kaharingan.

Tri Indrahastuti (2012: 31) mencatat bahwa Kaharingan berasal dari bahasa Sangen (Dayak kuno) yang akar katanya adalah "Haring" yang berarti ada dan tumbuh atau hidup yang dilambangkan dengan Batang Garing (dibaca batang haring) atau Pohon Kehidupan. Inti dari filosofi pohon kehidupan adalah keseimbangan atau keharmonisan antara sesama manusia, manusia dengan alam, dan manusia dengan Tuhan. Sebagai kepercayaan, kaharingan memuat tentang aturan hidup dengan nilai dan isinya yang bukan sekedar adat-istiadat, tapi juga ajaran berperilaku yang secara turun-temurun disampaikan secara lisan. Kaharingan telah ada sejak awal penciptaan bagi masyarakat suku Dayak, yaitu sejak awal Raying Hattala menciptakan manusia beriburibu tahun sebelum masuknya ajaran agama Hindu, Budha, Islam, dan Kristen. Raying Hattala merupakan sebutan Tuhan yang merupakan sumber segala kehidupan bagi masyarakat Kaharingan. "Ranying" berarti Maha Tunggal, Maha Agung, Maha Mulia, Maha Jujur, Maha Lurus, Maha Kuasa, Maha Tahu, Maha Suci, Maha Pengasih dan Penyayang, Maha Adil, kekal, Abadi, Maha Mendengar, sedangkan "Hattala" artinya Maha Pencipta.
Agama Kaharingan memuat kepercayaan tentang makhluk-makhluk halus atau roh (bali) yang terdapat di berbagai tempat. Kepercayaan terhadap roh dan makhluk halus ini kemudian diwujudkan melalui upacara-upacara keagamaan. Maunati (2006: 81) menjelaskan bahwa dalam kaharingan terdapat tiga jenis roh yang mereka percayai yaitu roh baik, roh jahat, dan roh yang tidak dapat diduga. Roh baik seperti Bungan Malan PeSelung Luan biasanya dipuja dalam upacara keagamaan masyarakat kaharingan. Contoh roh baik lain misalnya bali uma' (roh penjaga rumah panjang), bali utung (roh penjaga penghuni rumah), bali uman (roh baik padi), bali kamat dan bali suen (dipercaya dapat memberi keberanian dan ketrampilan pada manusia khususnya dalam berburu kepala). Sementara hal kematian, sakit, dan perasaan tidak menyenangkan seperti kecemburuan dan keraguan disebabkan oleh roh jahat. Roh yang tidak dapat diduga antara lain bali engkau (roh petir) dan bali pelaki (roh yang bersarang di tubuh burung elang). Jika burung elang terbang dari kiri ke kanan merupakan pertanda baik, dan begitu pula sebaliknya.

Masyarakat Dayakjuga mempercayai mite-mite yaitu cerita dewa-dewa, roh atau makhluk halus dan segala yang berhubungan dengan animisme. Mite sebagai cerita yang mempunyai latar belakang sejarah sangat dipercayai oleh masyarakat Dayak, dianggap sebagai cerita suci, dan menjadi landasan dalam menata kehidupan untuk kemudian muncul dalam berbagai ketentuan seperti adat dan ritus. Masyarakat Dayak pada umumnya mempercayai tiga cerita suci (mitos) yaitu tentang asal muasal atau terciptanya alam semesta, manusia pertama dan keturunannya, serta mitos tentang asal muasal padi (Radam, 2001: 161). Mitos-mitos itu terus tumbuh dan berkembang, sehingga keyakinan akan kehadiran roh-roh tertentu yang akan menjaga dan melestarikan alam semesta juga terus bertumbuh seiring dengan keyakinan masyarakatnya.

Ketika agama-agama besar mulai masuk ke wilayah Indonesia dan berpengaruh kuat pada masyarakat, termasuk diantaranya berpengaruh pada masyarakat Dayak, berangsur-angsur menggeser keyakinan yang telah turun temurun diwariskan leluhur. Saat ini sebagian besar masyarakat Dayak telah beralih memeluk agamaagama yang diakui negara, meskipun dalam 
kehidupan sehari-harinya keyakinan terhadap kepercayaan lama masih melekat dan menjadi bagian dalam kehidupan mereka.

Sebagian besar masyarakat Dayak memeluk agama Kristen, bahkan bisa dikatakan agama Kristen menjadi ciri khas masyarakat Dayak saat ini. Melalui proses akulturasi, orang Dayak yang memeluk agama Kristen masih melakukan adat tradisi leluhur. Dalam kehidupan budaya Dayak, akulturasi terjadi dalam suatu proses dialektika antara kepercayaan asli Dayak (kaharingan) dengan Kristen. Teologi Kristen telah memberi ruang yang luas bagi berlangsungnya proses dialektika itu, sehingga memungkinkan munculnya interpretasi-interpretasi baru yang kemudian mengerucut menjadi suatu sintesis. Sintesis tersebut merupakan suatu pilihan strategis yang ditentukan oleh masyarakat Dayak yang memeluk agama Kristen agar dapat menjalankan tata aturan hidup sesuai ajaran baru yang dipeluknya tanpa harus benarbenar menanggalkan keyakinan lama, sehingga eksistensi kesukuan Dayak masih terus bertahan.

Lain halnya dengan sebagian orang-orang Dayak yang memeluk agama Islam. Dalam norma-norma agama Islam, ada hal-hal yang berseberangan dengan adat tradisi Dayak, misalnya dalam pelaksanaan ritus-ritus adat Dayak yang seringkali menggunakan binatang-binatang yang dianggap haram oleh agama Islam sebagai bagian dari kebutuhan ritus dan bahkan menjadi elemen penting dalam kehidupan masyarakat Dayak. Contoh yang paling sederhana adalah penggunaan babi sebagai bagian penting dalam upacara adat dan kehidupan masyarakat Dayak. Oleh sebab itu, ketika memeluk agama Islam, mereka berangsur-angsur tidak lagi melakukan cara hidup berdasarkan adat dan tradisi budaya Dayak. Dalam konteks ini, masyarakat Dayak mengadopsi sepenuhnya tata cara hidup dan tata peribadatan Islam. Orang Dayak yang beragama Islam itu selanjutnya meninggalkan adat tradisi leluhurnya dan memilih identitas yang baru sebagaimana yang dianut oleh orang-orang Melayu. Norma-norma agama Islam yang ketat tampaknya tidak memberi ruang bagi perkembangan adat dan tradisi Dayak lama, yang menyebabkan sebagian dari masyarakat Dayak kemudian merasa kehilangan jati dirinya. Menurut Maunati (2006: 85), orang-orang Dayak yang memeluk agama Islam ini kemudian menyebut dirinya sebagai orang Melayu, yang jumlahnya mencapai $90 \%$ dari seluruh jumlah penduduk Melayu di Kalimantan.

Bagi Usman, penata tari Tatag De Penyawo, identitas baru ini dirasakan sebagai sebuah

tekanan. Dirinya merasakan terhegemoni atas kekuatan agama, yang seolah-olah memaksanya untuk menanggalkan identitas kesukuannya. Hal itu menimbulkan kegelisahan karena ia senantiasa mempertanyakan asal muasal dan identitias dirinya. Kegelisahan ini akhirnya memunculkan ide-ide kreatif penciptaan karya tari, yang sesungguhnya merupakan kegelisahannya akan jati diri dan identitas budaya yang melekat pada dirinya. Dari kegelisahan inilah pada akhirnya lahir karya tari yang berjudul Tatag De Penyawo, yang merupakan upaya untuk mencoba meredefinisikan dirinya sebagai orang Dayak yang memeluk agama Islam. Pelacakannya akan nilai-nilai yang ada dalam masyarakat Dayak, pengalaman religiositas dan spiritualitasnya, serta berbagai teknik ketubuhan menjadi modal dalam menciptakan karya tari ini, dan hal itu akan direfleksikan kembali dalam bentuk sebuah tatanan pertunjukan tari kontemporer.

\section{Ekspresi Pengalaman Koreografer}

Usman Najrid Maulana lahir dan besar sebagai Suku Tidung yang beragama Islam. Suku Tidung merupakan kerabat dari sub-suku Dayak Murut yang mengembangkan kerajaan Islam, sehingga tidak dikategorikan sebagai bagian dari rumpun Masyarakat Dayak, tetapi dianggap sebagai masyarakat Melayu sebagaimana suku Banjar, Kutai, dan Paser (Maulana, 2013: 6). Lingkungan dan keluarga mengajarkan tata cara hidup sebagaimana suku yang berbudaya Melayu, tetapi ketika dewasa ia yang banyak berkecimpung dalam dunia seni dan tradisi justru semakin banyak bersinggungan dengan adat tradisi masyarakat Dayak. Kegiatan-kegiatan seni pertunjukan yang diakrabinya pada umumnya merupakan bagian dari ritual upacara adat dan keagaman masyarakat Dayak, yang baginya berseberangan dengan ajaran keluarga dan lingkungan masa kecilnya. Konflik personal ini yang kemudian melatarbelakangi munculnya ide/gagasan untuk menciptakan karya tari yang menceritakan kelahirannya yang secara garis keturunan adalah seorang manusia Dayak. Ia tumbuh dan menyadari bahwa identitas bawaan dan keinginan hidupnya saling bertolak belakang. 
Ia menyadari dalam tubuhnya mengalir darah Dayak, tetapi konstruksi sosial dan keagamaan memutus aliran darah itu. Tubuhnya berada dalam situasi ambigu, apakah sebagai tubuh yang mewadahi tradisi Dayak, ataukah tubuh dalam konstruksi sosial keagamaan. Ada semacam perebutan identitas atas tubuh itu. Di sini ia mencoba mengambil sikap, berusaha memposisikan dirinya dengan meredefinisikan kedayakan dan keislamannya melalui karya tari ciptaannya yang diberi judul Tatag De Penyawo.

Karya tari ini dibawakan oleh sembilan penari laki-laki yang memvisualisasikan kegelisahannya tentang identitas. Mode penyajian karya tari ini adalah simbolis representasional, yaitu penyampaian pesan menggunakan gerak simbolis yang terkadang tidak dapat langsung dikenali maknanya oleh penonton. Karya tari ini merupakan karya tari dramatik dengan musik ilustratif yang memberikan energi dan kekuatan dalam penyajian karya tari. Adapun Gerak tari dalam karya ini menginterpretasikan gerakan tari Hudoq Kita' yang berupa gerakan hentakan kaki, melangkah maju, dan gerak tangan melambai atau mengayun ke depan dan ke belakang (Maulana, 2013: 7).

\section{Hudog Kita`Sebagai Inspirasi Artistik}

Sember penciptaan karya seni bisa berupa apa saja. Pengalaman mendengar, melihat, membaca, dan mengalami bisa menjadi sumber inspirasi untuk berkarya seni. Kejadian seharihari di dalam masyarakat seringkali menjadi inspirasi menarik bagi seorang seniman untuk mengekpresikannya kembali ke dalam wujud karya seni. Melalui proses yang unik dan personal, seorang seniman akan melakukan improvisasi dan eksplorasi sampai mewujudkan bentuk seni yang diinginkan. Dalam hal ini koreografer Tatag de Penyawo sesungguhnya ingin membagikan perasaan dan kegelisahannya sebagai orang Dayak yang beragama Islam. Pengamatannya yang intens pada sebuah upacara Pelas Tahun menuntunnya untuk melakukan kerja kreatif menciptakan sebuah karya tari.

Pelas Tahun adalah sebuah upacara adat yang digelar oleh masyarakat suku Dayak sebagai bentuk ungkapan syukur atas hasil cocok tanam sekaligus sebagai wujud harapan akan hasil yang lebih baik untuk panenan yang akan datang. Umumnya upacara ini digelar setelah selesai menugal, yaitu sebuah tahapan dalam tata cara bercocoktanam secara tradisional di wilayah Kalimantan, yaitu menyiapkan lahan agar siap ditanami dengan cara membuat lubang-lubang kecil di tanah dan menaburkan benih ke dalam lubang-lubang itu.

Sarana upacara ritual kesuburan ini adalah kehadiran tari Hudoq, yaitu penari yang mengenakan topeng berwajah binatang, gambaran dewa-dewa penjaga tanaman. Menurut kepercayaan masyarakat Dayak, Hudoq ini akan menjadi media kehadiran dewa yang akan melindungi tanaman dari hama dan perusak tanaman yang lain, sehingga pada saatnya kelak dapat memberikan hasil yang mencukupi kebutuhan pangan warga masyarakat. Dalam upacara Pelas Tahun, topengtopeng Hudoq yang berjumlah belasan akan menjadi media kehadiran roh/dewa. Mereka akan menari dengan cara menggoyang-goyangkan kostum yang terbuat dari dedaunan. Dengan cara berkeliling para penari melakukan gerak bergoyang-goyang dan diiringi dengan tetabuhan dari instrumen musik gong (PSN, 2005). Gerak menggoyang-goyang busana yang terus berulang, dipercaya akan mampu menghalau hama dan gangguan-gangguan lain yang mencoba merusak tanaman yang baru tumbuh. Sesekali dilakukan gerak memutar ke kanan atau ke kiri, yang bermakna meraih kebaikan bila ke kanan, dan membuang kesialan bila berputar ke kiri. Bentuk topeng Hudoq sendiri bermacam-macam, sesuai dengan bentuk roh pelindung masyarakat Dayak yang juga terdiri dari sub suku yang beragam.

Dalam penelitiannya tentang masyarakat Dayak Kenyah yang tinggal di desa Pampang Samarinda, Indrahastuti (2012: 31) melaporkan bahwa upacara Pelas Tahun dilaksanakan setahun sekali, yaitu di bulan Juni. Hudoq yang digunakan dalam upacara ini adalah Hudoq Kita', yang dalam bahasa setempat berarti hudoq cantik, simbol dewi pelindung tanaman. Topeng Hudoq cantik ini terbuat dari untaian manik-manik berwarnawarni yang membentuk lembaran cadar, dengan figure sebentuk wajah manusia di tengah lembaran cadar itu. Topeng yang berbentuk cadar itu dihiasi dengan semacam serabut berwarna terang di bagian atas yang membentuk semacam topi, sehingga bila topeng ini dikenakan akan menutup seluruh bagian kepala penari. Selain topeng yang menjadi elemen utama dalam tari Hudoq Kita', 
penari mengenakan atribut yang disebut kirip, yaitu bulu-bulu burung enggang yang dijepitkan di antara jari-jari tangan. Bagi masyarakat Dayak Kenyah dan masyarakat Dayak pada umumnya, burung enggang dipercaya sebagai burung penjaga desa.

Penampilan tari Hudoq Kita` dalam upacara Pelas Tahun di Pampang Samarinda menghadirkan 12 penari Hudoq Kita' yang semuanya adalah wanita berusia sekitar 40-60 tahun. Bagi masyarakat Dayak Kenyah para wanita penari itu akan menjadi media kehadiran dewi padi yang turun dari Apo Lagan tempat para dewa dan dewi tinggal. Roh-roh itu akan melindungi tanaman yang baru tumbuh, menghalau hama dan gangguan lain, agar kelak dapat menghasilkan panen yang melimpah.

Tempat upacara Pelas tahun di serambi lamin, rumah adat suku Dayak Kenyah di Pedalaman, merupakan pusat kegiatan sehari-hari. Ruang terbuka di halaman lamin yang digunakan untuk pelaksanaan upacara Pelas Tahun bermakna untuk mendekatkan seluruh warga masyarakat dengan lingkungan, agar terjadi keseimbangan dan hubungan yang harmonis antara manusia dengan alam sekitarnya. Alam yang merupakan sumber kehidupan harus dijaga kelestariannya agar senantiasa memberikan hasil melimpah.

Sesuai dengan namanya, Hudoq Kita' memiliki karakter yang feminine -lembut yang akan menonjolkan kecantikan seorang perempuan. Hal itu tampak dalam gerak tari Hudoq Kita' yang sikap dasar tubuhnya cenderung tegak, merendah dengan gerak kaki melangkah dalam volume kecil, serta yang sangat khas dalam tarian sakral ini adalah kibasan-kibasan kecil di kepala, sehingga hiasan kepala itu bergetar seiring dengan gerak kibasan kepala itu sendiri. Gerakan kepala itu tampak menjadi aksen dari gerak langkah kaki dan ayunan tangan dengan jemari menjepit kirip, yang dilakukan dengan volume kecil dan tempo pelan. Menekuk kaki dilakukan dalam setiap langkahnya, dan sesekali diberi aksen hentakan kaki semakin memperkuat kesan feminin dalam tari Hudoq Kita'. Keanggunan dan kecantikan gerak itu diperkuat dengan musik iringan yang terdiri dari instrumen gong, jatung, dan sape.

\section{Deskripsi Karya Tari Tatag De Penyawo}

Ketika tirai panggung proscenium dibuka perlahan, penonton langsung bisa melihat peman- dangan yang serba putih. Lantai tari telah dilapisi lembaran plastik putih, cyclorama yang dibuat dari kain putih, dan side wings semuanya serba putih. Pusat pandangan berada pada satu penari, laki-laki berpostur tubuh semampai yang duduk berselonjor merapatkan kaki di dead center proscenium stage. Ia membelakangi penonton, mengurai rambut panjangnya, menolehkan wajah ke arah kiri, seolah ingin berucap sesuatu kepada penonton di belakangnya. Selembar cawat putih dikenakannya, dan hanya itu saja yang menempel di tubuhnya. Di bagian belakang, yaitu di down center, 7 orang penari lain dalam balutan celana pendek merah menyala berdiri di dalam posisi horizontal. Mereka semua diam.

Perlahan penari bercawat putih itu merubah posisi duduknya. Ia menekuk kakinya, perlahan berdiri sambil merentang tangan dan menangkupkannya, kemudian berputar. Ketika ia sepenuhnya telah kembali membelakangi penonton, perlahan ia berjalan ke down center. Gerak berjalan itu mengingatkan pada gerak slow motion dalam film-film action. Dalam gerakan seperti ini ia kemudian menghilang ke center right, bersamaan dengan tujuh penari yang lain telah membentuk formasi menyebar. Mereka semua bergerak perlahan: melangkah, berputar, dan berjingkat menuju posisi masing-masing, sehingga proscenium terasa menjadi penuh karena formasi menyebar tersebut. Kualitas gerak yang ditampilkan begitu ringan, tidak membutuhkan kekuatan tenaga dan kelenturan, tetapi menyiratkan kebersamaan rasa yang diekspresikan dalam langkah-langkah ringan itu. $\mathrm{Ke}$ tujuh penari seolah telah memiliki ritme yang sama. Lantunan dendang Sansana Malahoi, sebuah syair tentang penciptaan manusia, dan pukulan bedug yang seirama detak jantung yang teratur menjadi pengiring bagian pembuka/ introduksi karya ini.

Selanjutnya mulai digelar bagian pertama. Pada bagian ini banyak ditampilkan gerak-gerak simultan, unison, dan rampak yang membutuhkan ketrampilan teknis yang sama diantara para penarinya. Meskipun perkusi bedug yang ajeng mengiringi bagian ini, tetapi ritme gerak tarinya tidak selalu mengikuti ritme musik pengiring. Rangkaian gerak yang ditampilkan merupakan perpaduan gerak dalam kecepatan yang bervariasi. Dalam satu rangkaian gerak terdapat kecepatan rendah dengan pola gerak mengalun, dan 
dipadu dengan gerak yang dilakukan tiba-tiba dalam kekuatan dan kecepatan tinggi, kemudian diakhiri dengan gerak pelan mengalun kembali. Perpaduan menarik dari gerak-gerak canon juga menjadi tatanan yang secara cerdas memecah keheningan dan keajegan ritme yang ditampilkan musik pengiringnya. Bagian ini didominasi oleh kekuatan teknik gerak mengangkat kaki, berputar, menjatuhkan diri, bangun dengan cepat dan berlari untuk tiba-tiba berhenti tanpa kehilangan keseimbangan. Dalam satu rangkaian selalu terdapat unsur gerak dengan mengalun lembut yang dipadu dengan gerak vibrasi pada bagian tubuh tertentu serta gerakan yang dilakukan tiba-tiba, sesaat, dan dalam kecepatan tinggi dan kekuatan penuh. Ditampilkan pula gerak-gerak dengan mengeksplorasi kekuatan penyangga tubuh yang bervariasi. Gerak ini membutuhkan ketrampilan teknik yang khusus, tetapi gerakgerak tersebut berhasil disajikan dengan baik karena kemampuan teknik para penarinya, serta diperkuat dengan pilihan penari yang memiliki postur tubuh yang hampir sama.

Semakin lama variasi gerak dan rangkaian gerak semakin rumit, panjang, dan kecepatan makin meninggi, dengan perkusi yang semakin cepat pula, sehingga memberikan suasana tegang dan cukup melelahkan. Tiba-tiba para penari menjatuhkan diri di lantai secara serempak, terlentang dan merentangkan kaki mereka, bersamaan dengan aksen musik perkusi menghentikan dentuman dan pukulan ritmenya. Selanjutnya dengan perlahan mereka berputar dan duduk berjongkok membelakangi penonton, lalu secara perlahan bergerak melangkah, menghilang di balik side wings. Ini adalah akhir bagian pertama.

Bagian kedua menyuguhkan suasana yang lebih tenang, yang dibangun dengan iringan musik yang berasal dari instrumen sape (sampek). Seorang penari yang mengenakan $G$ string sewarna kulit turun perlahan dari gantungan yang membungkusnya. Gerakannya sangat perlahan tetapi dengan detil gerak yang sangat rumit, hasil pengolahan eksplorasi gerak-gerak ingsutan kaki, berjingkat, melangkah, dipadu dengan gerak lengan dan pinggul yang sangat khas gaya Dayak. Beberapa saat penonton disuguhi sajian komposisi tari solo yang memikat, sampai tiba-tiba di bagian up right stage melayang kain panjang berwarna hijau. Disambarnya kain itu, lalu dikenakannya sebagai cawat. Kibasan kain ketika dikenakan sebagai cawat membentuk disain melayang yang unik dan menarik, apalagi ketika di bagian up right muncul property lain yaitu topeng Hudoq Kita' yang segera dikenakannya, seolah menjelmakan penari itu sebagai sosok manusia Dayak yang sangat eksotis. Selanjutnya karakter dan tipe gerak yang disajikan secara solo ini semakin menunjukkan ciri karakteristik gerakan tari Dayak yang anggun - feminin, yang dibangun dari gerak lambaian tangan, kibasan kepala, sikap tubuh, posisi kaki, langkah, dan jingkat kakinya. Komposisi tunggal ini terasa pendek ketika dari bagian belakang stage yaitu di up right stage muncul berderet 7 penari mengenakan topeng hudoq kublo', yaitu kreasi pengembangan topeng Hudoq Kita`. Property ini menutupi seluruh bagian kepala hingga dagu penari, karena berupa semacam topi cadar tinggi dengan rumbai kain warna-warni.

Ke tujuh penari melakukan gerak langkah cepat dengan memegang sehelai kain hijau panjang. Beberapa motif gerak bergulung cepat dengan permainan kain panjang itu tampak sangat kontras dengan penari yang mengenakan topeng budoq kita yang terus menampilkan disain-disain gerak feminin lembut dalam gaya spesifik Dayak. Dominasi tujuh penari semakin kuat, seiring dengan berlalunya penari Hudoq Kita' dengan langkah jingkat. Perpindahan perhatian kepada penari kelompok ini menandai diawalinya bagian terakhir karya tari ini.

Selanjutnya suguhan disain yang dibangun dari kain panjang kembali muncul ketika ketujuh penari dengan caranya sendiri-sendiri mengenakan kain panjang itu sebagai cawat. Kekuatan kibasan lengan ketika melilitkan kain diantara kedua paha dan pinggangnya memunculkan disain kain-kain yang melayang di udara dengan lembut. Kibasan dan lilitan terus dilakukan, sampai tersisa ujung kain yang kemudian dibiarkan berjuntai dari pinggang ke bagian depan dan belakang tubuh. Selesailah ke tujuh penari mengenakan cawat hijaunya, untuk kemudian beralih menyuguhkan pola-pola gerak lain yang tampak lebih atraktif dan dinamis. Kecepatan dan keajegan ritme gerak sangat menonjol dalam bagian ini dan oleh karena dilakukan dengan rampak serempak maka suasana menjadi lebih semarak. Bila di bagian lain ekspresi kedalaman rasa dan jiwa mendapat porsi lebih banyak, maka pada bagian ini lebih 
banyak ditampilkan disain-disain gerak yang ornamentik, ringan, dan semarak, sehingga terasa sangat "menari" dan membuai. Gambaran akan etnis Dayak sangat kental pada bagian ini, karena elemen-elemen yang digunakan, yaitu elemen gerak, iringan, karakter, property, dan atribut lainnya sangat lekat dengan ekspresi tari tradisi Dayak.

Kesemarakan komposisi tari ini tiba-tiba terusik dengan kehadiran kembali penari bercawat putih yang dengan pelan memecah meriahnya komposisi kelompok itu melalui gerak langkah kaki yang teratur, dengan lambaian tangan ringan sebagai penyeimbang langkahnya. Ia melangkah seolah tidak hirau dengan permainan komposisi ruang dan gerak berjingkat yang tengah dilakukan penari kelompok dalam formasi diagonal. Sementara komposisi kelompok terus melakukan locomotor movement dengan berjingkat, melambai, dan mengibas, penari bercawat putih dengan tenang mengambil posisi di dead center stage, duduk berselonjor kaki membelakangi penonton, dan menoleh ke kiri, sama seperti ketika dilakukan di bagian pembuka tarian. Special light yang diarahkan padanya semakin meredup, seirama dengan dendang Sansana Malahoi yang makin menghilang dari pendengaran.

\section{Analisis Koreografi}

Sebuah karya tari adalah ekspresi, ungkapan jiwa dan rasa penata tari. Sebuah karya seni bisa jadi merupakan ekspresi individu dari para pelakunya, tetapi juga merupakan ekpresi komunal masyarakat penyangga dan pendukungnya.

Tatag De Penyawo dalam bahasa setempat berarti rasa kehilangan yang sangat mendalam (Maulana, 2013: 13). Dalam konteks karya tari ini yang dimaksudkan kehilangan adalah kehilangan identitas sebagai orang Dayak. Apakah benar kehilangan identitas itu? Ataukah sesungguhnya ia gelisah dalam upaya mengambil posisi dalam mendefinisikan ulang identitas-identitas yang ada dalam dirinya, yaitu identitas Dayak yang diwariskan leluhurnya, dan identitas yang dikonstruksikan oleh lingkungan sosial dan keagamaannya.

Perantauannya di tanah seberang, bukannya semakin menjauhkan identitas kesukuannya itu, tetapi justru semakin mengingatkan dan menyadarkannya akan kehadiran dirinya sebagai orang
Dayak. Penata tari ingin merefleksikan kegelisahan itu dengan menampilkan karya ini. Bagaimana kegelisahan itu diungkapkan, tentu menjadi bagian yang menarik untuk mengkajinya, yaitu dengan menguraikan elemen-elemen pembangun koreografi itu yang meliputi penari, struktur ruang, dan waktu. Elemen tersebut kemudian dipahami sebagai bahasa simbol dan media ungkap kegelisahannya.

\section{Pemilihan Penari}

Tatag de Penyawo adalah komposisi tari kelompok, yang terdiri dari 9 orang penari laki-laki. Penyebutan akan koreografi kelompok didasarkan atas jumlah penari pendukung, yang satu sama lain memiliki ketergantungan fungsi untuk membentuk satu kesatuan yang utuh, sehingga dapat dianalogikan sebagai sebuah kesatuan organisma (Hadi, 2003: 1). Penentuan jumlah penari perlu mendapat perhatian penting, karena melalui merekalah penata tari mengkomunikasikan gagasannya. Dalam karya ini pilihan penari laki-laki adalah hal yang pertama dilakukan, karena penata tari menginginkan penaripenarinya akan menjadi cerminan atau gambaran dirinya sendiri yang berjenis laki-laki. Postur tubuh menjadi kriteria berikutnya, karena harus memiliki kemiripan dengan postur tubuh penata tari, yakni penari dengan postur tubuh sedang dan kaki-kaki yang jenjang. Kemiripan postur dan tinggi rendah tubuh akan sangat menguntungkan untuk jenisjenis garapan kelompok non drama tari. Tanpa ada penokohan dan peran, pilihan kesamaan postur akan menjadikan gerak-gerak rampak menjadi lebih optimal, dan meminimalisir kerepotan ketika akan menempatkan penari dalam formasi tertentu.

Pilihan terpenting untuk para penari adalah kemampuan teknik tari yang prima. Modal dasar seorang penari adalah kemampuan dan kecerdasan tubuhnya untuk melakukan gerak-gerak sesuai dengan kebutuhan dan tuntutan tekniknya. Tanpa bekal kemampuan teknik yang baik, maka pesan yang ingin disampaikan kepada penonton tentu tidak akan sampai. Oleh karena itu, seorang penata tari akan memilih penari-penarinya yang memiliki kemampuan teknik gerak dan kecerdasan tubuh sesuai dengan tuntutan karya yang akan dilahirkannya, karena sebelum memulai proses 
latihan pun, penata tari telah memiliki gambaran kasar akan gerak-gerak yang akan digarapnya.

Melihat sajian koreografi Tatag de Penyawo, maka kriteria penari yang dibutuhkan adalah mereka yang memiliki stamina tinggi, lentur, mampu melakukan teknik gerak jatuh-bangun, bergetar, serta memiliki daya imitasi yang baik. Di samping itu, kepekaan akan ritme juga menjadi tuntutan tersendiri, karena dalam karya ini banyak dilakukan gerak-gerak rampak yang ritme geraknya tidak selalu selaras dengan ritme musik pengiringnya. Sebagai contoh ada satu rangkaian gerak yang terdiri dari gerak tangan mengayun pelan, kemudian tiba-tiba tubuh bergetar, lalu lari dengan cepat, dan diakhiri dengan berhenti mendadak. Rangkaian gerak seperti akan sangat terasa "kering" bila dilakukan seiring dengan ketukan perkusi pengiringnya, tetapi akan menjadi lebih hidup dan bermakna, ketika dilakukan dengan ritme gerak penarinya sendiri yang muncul dari kedalaman rasa. Tantangan akan muncul ketika gerak itu harus dilakukan bersama dalam kelompok, sehingga perlu diupayakan melalui latihan-latihan bersama untuk menyatukan ritmeritme dan rasa gerak para penarinya.

Perpaduan antara postur tubuh, kelenturan, stamina, ketrampilan teknik, dan kepekaan ritme ini akan makin lengkap bila penari memiliki kesadaran ruang yang baik. Kepekaan akan ruang antara, jarak antara, posisi, dan arah sangat dibutuhkan dalam garapan koreografi kelompok. Akan terasa sangat mengganggu bila dalam satu formasi berderet, jarak antar penari tidak rata karena penarinya tidak cukup peka dengan jarak antara. Apalagi bila dikaitkan dengan pencahayaan, maka apabila seorang penari tidak tepat posisinya, ia akan kehilangan fokus pencahayaan. Bila hal itu terjadi, akan sangat mengganggu sentuhan emosi dan merusak keutuhan garap koreografinya.

Sembilan penari yang dipilih untuk membawakan karya tari ini telah berhasil memenuhi tuntutan penata tari dalam hal-hal tersebut di atas, ditambah dengan sebagian dari mereka tampak telah memiliki pengalaman yang cukup dalam hal penampilan tari kontemporer. Keberhasilan itu tidak lepas pula dari kemampuan koreografer dalam mentransfer teknik dan cita rasa gerak yang dibuatnya untuk dilakukan seluruh penari, sehingga dalam komposisi kelompok tidak tampak ada seorang penari yang tampak lebih menonjol dari yang lainnya.

Lain halnya dengan pilihan penari tunggal dalam karya ini. Dalam karya ini ada 3 bagian yang menampilkan penari solo, yaitu bagian awal, bagian ke dua, dan bagian akhir. Pada bagian awal dan akhir komposisi solo ditampilkan sendiri oleh penata tarinya. Ada keuntungan tersendiri bila seorang penata tari menjadi penari dalam karyanya, karena ia tahu persis apa yang diinginkan untuk diekspresikan. Untuk komposisi solo pada bagian ke dua, pilihan penari lebih selektif karena keberhasilan komposisi itu hanya tergantung pada satu orang itu, sehingga harus dipilih penari yang sangat tinggi kemampuan teknik tarinya. Penari itu juga harus memiliki daya imitasi yang kuat, karena pada bagian solo ini banyak ditampilkan motif gerak yang diambil dalam tarian tradisi Dayak. Oleh karenanya, penari itu harus mampu menirukan pola gerak dengan teknik yang sesuai ketentuan, serta harus mampu pula mengungkapkannya dengan kedalaman rasa sesuai tuntutan ekspresi tarinya.

\section{Gerak dan Pola Lantai}

Apabila penari menjadi intrumen dalam sebuah karya tari, maka media untuk mengungkapkan adalah gerak. Keduanya menjadi bagian yang tidak terpisahkan dalam sebuah koreografi, karena hal itulah yang menjadi elemen utama koreografi.

Materi gerak dalam karya tari ini adalah motif gerak yang ada dalam tari Hudoq Kita', yang berupa gerak berjalan melenggang dan melangkah menghentakkan kaki. Unsur-unsur gerak dalam tari tradisi tersebut benar-benar dicermati, untuk kemudian dilakukan eksplorasi dan pengembangan, sehingga melahirkan berbagai motif gerak berjalan atau berpindah tempat (locomotor movement) dengan disain, ornamen, volume, level, ritme, dan variasi penggunaan energi yang sangat kaya. Beberapa nama motif gerak berpindah tempat ini adalah tanok diwa, gantak, dan guang kati guang (gambar 1). 


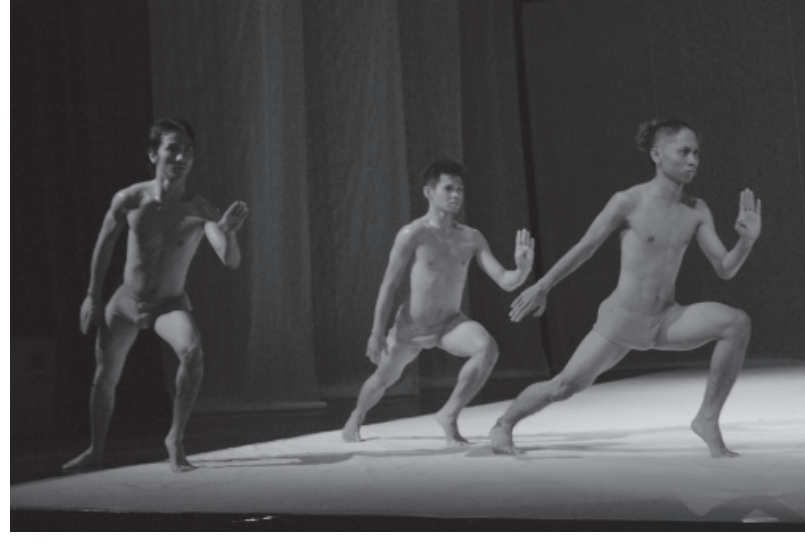

Gambar 1. Sikap dasar tubuh dalam motif gerak guang kati guang (Foto: Maulana, 2013)

Sebagaimana jenis locomotor movement, dalam karya ini gerak di tempat (stationary, body movement) juga mendapat perhatian yang serius dalam pengolahannya. Body movement di sini banyak ditemukan dari pengolahan dan pencarian dari gerak keseharian, vibrasi, mengayun, memutar, meliuk, serta pengolahan variasi tumpuan badan. Baganak, gentimung, iluk jiwa, bepakot, dan muyak adalah beberapa contoh body movement yang ada dalam karya tari ini.

Sumber gerak yang diolah menjadi rangkaian gerak tari ini bersumber dari sikap dasar gerak tubuh dan gerak keseharian orang Dayak. Salah satu contohnya adalah sikap duduk berselonjor yang ditampilkan pada bagian paling awal tarian. Sikap duduk seperti ini adalah sikap duduk yang paling sopan yang harus dilakukan orang Dayak ketika berada di antara tetua. Kedua kaki lurus dan rapat satu dengan lainnya, sedangkan tangan ditangkupkan di atas paha. Sikap kepala dan pandangan tidak boleh mendongak, karena itu menunjukkan ketidaksopanan. Ketika sikap ini ditampilkan di bagian awal dan akhir, ada pesan yang disampaikan, bahwa ia tetap berusaha menjaga kesopanan dalam menuturkan perasaan dan gejolak hatinya, juga sebuah kesadaran bahwa hendak bertutur di depan tetua.

Kegelisahan dan konflik batin yang menjadi tema dalam karya koreografi ini disampaikan dalam rangkaian gerak yang mengekspresikan perilaku religius orang berdoa, dirangkai dengan gerak vibrasi tubuh, berlari, dan terhenti tibatiba, untuk kemudian dilakukan gerakan serupa beberapa kali dalam variasi yang berbeda-beda. Ada kesan seolah ingin lari dari sesuatu yang

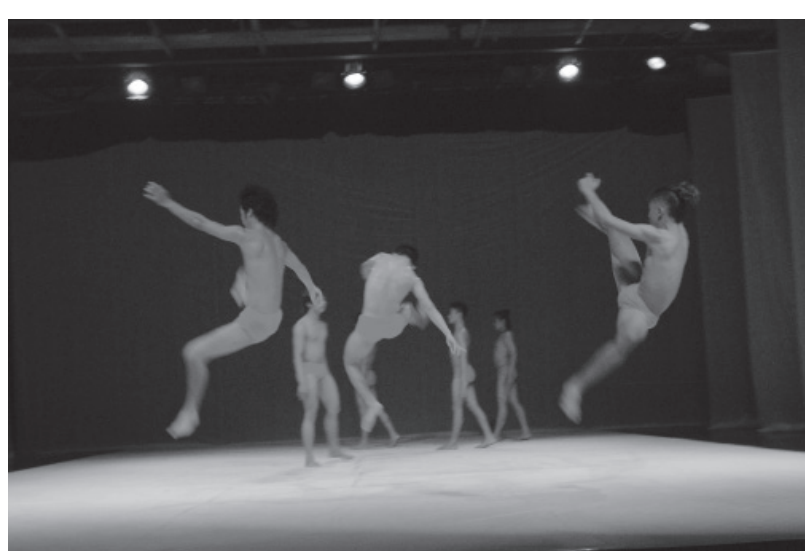

Gambar 2. Gejolak batin yang digambarkan dalam gerak melenting ke udara (Foto: Maulana, 2013)

terasa mengikat, tetapi ikatan itu begitu kuat untuk dilepaskan. Kesan putus asa dan seolah tak ada harapan diwujudkan dalam rangkaian gerak dengan menggeliat, melenting, dan berguling menjatuhkan diri (gambar 2). Kualitas gerak yang begitu kuat untuk menggambarkan konflik batin itu semakin terasa menyentuh karena kemampuan para penari mengekspresikannya dengan baik.

Gambaran akan keriangan dalam menjalani hidup dimunculkan dalam rangkaian gerak yang tampak lebih ornamentik, ritmis, dan dipadu dengan iringan yang lebih melodis. Gerak-gerak ini terdapat pada bagian ke tiga, yang banyak mengeksplorasi gerak berjingkat, berkibas, dan melambaikan tangan. Corak gaya gerak tari Dayak kuat, dengan hampir seluruh elemen ekspresi tari Dayak digunakan yaitu sikap tubuh, pola gerak, iringan, serta atribut busananya.

Pengolahan materi gerak tari Dayak dengan interpretasi dan pengembangan yang variatif itu merupakan bahasa ungkap yang dipilihnya untuk memposisikan diri dalam situasi yang ambigu. Pengalaman ketubuhan Dayak menuntunnya untuk kembali kepada identitas lamanya, sehingga dengan sengaja ia mengusungnya sebagai materi utama dalam karya ini. Idiom-idiom gerak Dayak yang diserap itu dihadapkan dengan idiom-idiom dan ikon-ikon gerak tari Melayu yang diwakili dengan gerak langkah kaki yang mengingatkan pada gerakan tari Zapin. Hal ini tampak misalnya dalam gerak iluk diwa. Meskipun ikon tari Melayu yang diwakili dengan langkah zapin itu tidak selalu identik dengan Islam, tetapi ikon tari Melayu sengaja diambil karena dipandang sebagai representasi atas identitas baru yang dianggap 
telah menghegemoni dirinya. Sayangnya, porsi pemberian ikon Melayu ini sangat sedikit ditampilkan.

Cara penata tari mencoba memosisikan dirinya juga terbaca dari kehadiran gerak yang secara simbolis menggambarkan orang sedang beribadah. Diambilnya sikap orang akan bersholat dan diperkuat dengan lantunan ayat suci sebagai ilustrasi. Tampaknya ia pun merasakan terhegemoni dengan kekuasaan agama, sehingga membuat tubuh bergetar dan meronta, lalu lari. Pola itu dilakukan beberapa kali, sehingga menimbulkan sentuhan emosi yang mengharukan. Bagian ini tampaknya ingin dimanfaatkan oleh penata tari untuk mengungkapkan kegelisahan, kegamangan, dan gejolak batiniahnya. Ikon-ikon keislaman dan kemelayuan yang ditampilkan dalam pola-pola gerak dan porsi yang terlalu sedikit, memberi kesan bahwa penata tari ingin kembali ke identitas lama, yaitu tradisi budaya Dayak.

Dalam sebuah koreografi kelompok, penempatan penari dalam sebuah formasi / pola lantai menjadi daya tarik tersendiri dan akan membantu menciptakan sentuhan emosional dan dinamika dalam pertunjukan. Untuk menciptakan sentuhan emosional dalam panggung proscenium, perlu mempertimbangkan pusat perhatian dengan menempatkan penari titik tertentu sesuai dengan kuat lemahnya area stage. Secara konvensional di dalam panggung proscenium terdapat 7 area yang dianggap kuat dan 6 area lemah (Hadi, 2003: 31). Di samping menempatkan penari pada posisi yang sesuai dengan kebutuhan koreografi, maka dalam koreografi kelompok dapat dilakukan dengan cara membagi pusat perhatian. Hal ini dilakukan oleh koreografer Tatag De Panyawo dalam membuat formasi-formasi penari.

Formasi yang kuat untuk gerak rampak (unison) adalah satu pusat perhatian (focus on one point) (gambar 3). Agar kerampakan gerak dapat ditampilkan optimal, maka jarak antara penari sebaiknya dipersempit. Salah satu contoh pola tersebut terdapat dalam gerak rampak pada bagian pertama, ketika ke tujuh penari berada di wilayah $u p$ right dengan gerak rampak simultan yang dilakukan dengan cepat. Pola ini sangat menguntungkan, karena ritme gerak tidak dituntun oleh ritme iringan tari, sehingga kesatuan rasa gerak penari menjadi andalan untuk dapat melakukan gerak rampak yang cepat tersebut. Akan menjadi

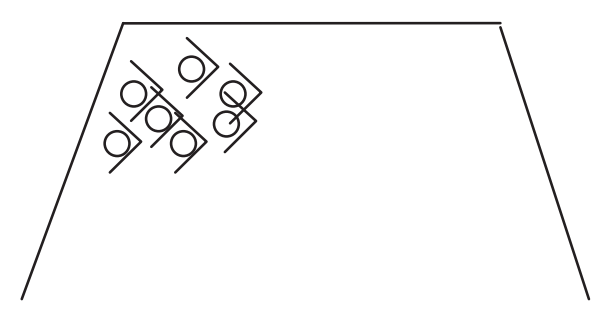

Gambar 3. Focus on one point dalam gerak rampak simultan (Foto: Maulana, 2013)

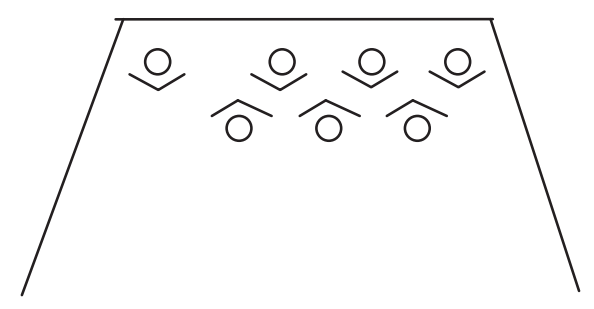

Gambar 4. Focus on one point pada gerak gentimung (Foto: Maulana, 2013)

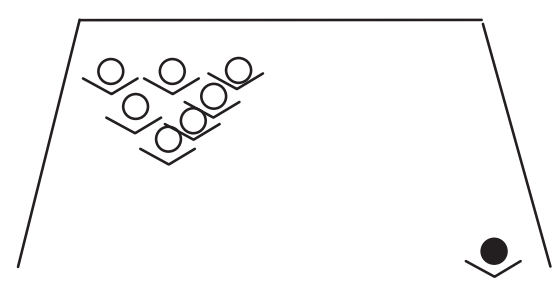

Gambar 5. Focus on two points (Foto: Maulana, 2013)

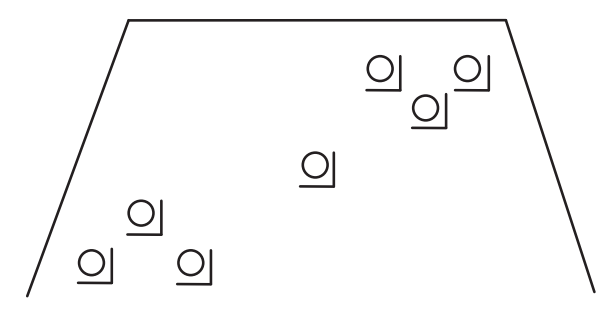

Gambar 6. Formasi focus on three points dalam bagian ke tiga (Foto: Maulana, 2013)

kendala tersendiri apabila gerakan ini dilakukan dalam formasi yang menyebar. Apabila dilihat dari formasi berkelompok di wilayah up right dengan arah hadap ke samping, sesungguhnya bukan wilayah yang memberi sentuhan emosi kuat. Akan tetapi karena dilakukan dalam jarak antara yang sempit menyebabkan penari dapat melakukan gerak rampak cepat dengan optimal, sehingga memunculkan kesan yang kuat, menyiratkan kebersamaan, dan kekokohan. 
Untuk gerakan yang relatif lebih pelan, focus on one point dapat dilakukan dalam posisi yang berderet atau menyebar, seperti pada gerak gentimung yang dilakukan dalam formasi berbanjar di wilayah up center. Wilayah ini bukan wilayah kuat yang mampu memberikan sentuhan emosional. Gerak gentimung yang dilakukan di wilayah ini tampak menjadi kuat bukan karena penempatan formasi, tetapi karena pola gerak dan suasananya sangat menghanyutkan (gambar 4). Pola ini dipecah dalam bentuk canon, sehingga sehingga suasana yang diinginkan dapat tercapai.

Pembagian pusat perhatian menjadi dua (focus on two points) ditemukan pada bagian ke dua, ketika penari tunggal solo berada di down left menari dalam pola gerak tradisi Dayak, sementara di bagian up right tujuh penari dalam formasinya membawa lembar kain hijau panjang. Meskipun dilakukan dalam arah hadap yang sama, kesan yang muncul adalah dua hal yang berbeda (gambar 5). Pada formasi ini penata tari akan menyatakan dirinya sebagai orang Dayak baru.

Contoh Focus on three points dalam gerak rampak simultan yang kemudian dipecah menjadi pola gerak canon tampak dalam formasi pada bagian ke tiga karya tari (gambar 6). Kesesuaian formasi dengan pola gerak dan arah hadap penari akan memberikan sentuhan emosi yang berbedabeda, dan hal ini akan menjadi sumbangan yang sangat berarti bagi pencapaian suasana dramatik yang diperlukan dalam karya tari. Demikian pula halnya dengan pertimbangan jarak antara atau ruang antara yang dibangun dari disain gerak maupun formasi penari akan memunculkan sentuhan rasa yang berbeda. Seringkali menurut perhitungan artistik pola-pola tertentu kurang menguntungkan, tetapi kenyataannya justru pola tersebut bisa menjadi sangat kuat sentuhan emosinya.

\section{Iringan Tari}

Iringan tari merupakan salah satu faktor penting yang mampu membangun suasana, dapat menghasilkan penguatan terhadap garapan tari, serta mampu membentuk atmosfir yang mampu menyatukan seluruh gagasan (Sarjiwo, 2011: 181). Fungsi musik dalam karya tari ini tidak semata bersifat ilustratif, tetapi hentakan beat, irama, serta warna musik itu memberikan energi serta kekuatan tersendiri dalam penyajian karya tari.
Musik pada iringan tari digarap sesuai dengan kebutuhan tari serta suasana yang diinginkan pada tiap bagiannya, sehingga pilihan bentuk dan struktur musik pun akan menyesuaikan kebutuhan tarinya. Di bagian awal, iringan berupa vokal tradisi kaharingan Sansana Malahoy yang ditambah dengan efek vokal delay yang memberi kesan berulang, bersahutan, dan berkesinambungan antara setiap lirik yang dinyanyikannya, sehingga memunculkan suasana damai dan tenang. Penggunaan vokal juga dilakukan pada bagianbagian lain, dengan menampilkan lantunan ayat suci Al-Qur'an surat Al-Hujarat ayat 13.

Pemanfaatan syair Sansana Malahoy dan ayat suci itu mengisyaratkan bahwa diri penata tari dihadapkan pada dua pilihan berat. Degub jantung dan irama hidupnya yang diwakili oleh tabuhan bedug menjadi tanda kegelisahannya untuk bersikap. Sansana Malahoy dilantunkan dengan begitu menyayat karena efek delay, seolaholah memanggil-manggilnya untuk kembali, sedangkan lantunan ayat suci terasa begitu menyejukkan. Kontras ini sengaja dibangun untuk menyatakan kebutuhan rohaninya terasa disegarkan dengan ayat-ayat suci. Melalui kedua jenis ini, maka dapat dilihat posisi penata tari sebagai seorang muslim yang disegarkan dan dihidupkan dengan ajaran Islam.

Tampilan musik pengiring diperkaya dengan tabuhan musik perkusi yang bersumber dari pukulan bedug dengan karakter suara rendah atau low section yang ajeg teratur seirama detak jantung, yang kian lama kian berubah kecepatan dan intensitasnya sesuai dengan kebutuhan karakter gerak dan suasana yang ingin dicapai. Dominasi musik perkusi ini sangat terasa pada bagian awal tarian.

Kesan dan suasana tradisi Dayak muncul dalam bentuk-bentuk musik ilustratif dan melodis yang dihasilkan dari alat musik tiup, gesek, dan petik yang sangat tipikal Dayak. Pada beberapa bagian terdapat efek-efek khusus dari permainan alat musik tiup yang diolah sedemikian rupa untuk menciptakan suasana tegang dan mencekam. Pada saat memasuki adegan kedua dimainkan alat musik petik tradisi yaitu sape' (sampek) yang wujud dan juga karakter suaranya dapat mewakili identitas suku Dayak. Selanjutnya dihadirkan juga beberapa alat musik berbahan perunggu seperti gong dan kelintangan yang timbre atau warna 
suaranya dapat membangun suasana agung. Tidak ketinggalan instrumen gendang digunakan sebagai pengatur tempo, dinamika, serta memberi aksen untuk gerak-gerak tertentu.

Di sinilah semakin jelas ke arah mana Usman akan melangkah. Hampir seluruh identitas musik Dayak diambil untuk menghidupkan karyanya itu. Perbandingan porsi yang kontras dalam hal materi iringan tari menguatkan pengambilan sikapnya atas identitas yang digelisahkannya. Ia tidak memilih untuk menghasilkan sebuah sintesa dari proses yang secara dialektis dilakukan, tetapi ia memilih untuk kembali ke akar tradisi moyangnya. Ia ingin menyandingkan identitas baru yang telah dikonstruksikan secara sosial itu dengan identitas lamanya.

\section{Rias, Busana, dan Property.}

Rias dan busana serta property merupakan elemen yang senantiasa hadir dalam sebuah pertunjukan tari. Ketiga hal itu seolah seperti halaman depan sebuah rumah. Itulah yang pertama kali terlihat penonton, sehingga penonton langsung dapat mengenali dan memberikan kesan. Di dalam karya tari Tatag De Penyawo busana yang dikenakan sangat sederhana, sehingga bagian-bagian tubuh penari sebagian besar tampak terbuka. Dari jenis yang sederhana itu, ada 3 macam busana yang dikenakan. Ketiganya seakan-akan hanya merupakan upaya menutup aurat saja. Namun tidaklah demikian adanya, karena ke 3 busana yang semuanya dikategorikan pakaian dalam itu memiliki dasar yang kuat dalam pemilihannya.

Busana yang pertama adalah celana pendek berwarna merah terang. Busana ini dikenakan oleh penari kelompok 7 orang pada bagian pertama tarian, dan tidak ada atribut atau asesoris lain yang dikenakan selain celana pendek merah itu saja. Kesan bersahaja langsung muncul ketika para penarinya masuk ke area pentas hanya bercelana pendek merah, tanpa rias di wajah, dan tanpa hiasan apa pun di bagian-bagian tubuh lain. Dengan tubuh yang dibiarkan terbuka seperti ini detil gerak dan kekuatan otot penari sangat tampak jelas terlihat, seperti ketika mengangkat kaki lurus ke samping. Ketegangan otot paha dapat dilihat penonton, demikian juga ketika melakukan liyukan tubuh, otot-otot bagian tubuh yang menegang dapat disaksikan oleh penonton.
Bentuk yang kedua adalah cawat. Ada dua warna cawat yang dikenakan, yaitu cawat berwarna putih dan cawat berwarna hijau. Bahan cawat itu adalah kain satin polos sepanjang 6 meter dengan lebar $35 \mathrm{~cm}$. Cawat putih dikenakan oleh penari tunggal di bagian introduksi dan bagian akhir, sedangkan Cawat hijau dikenakan oleh penari tunggal di bagian ke dua dan penari kelompok 7 orang di bagian ketiga karya tari ini. Penari tunggal yang muncul di bagian kedua hanya mengenakan $G$-string warna kulit, sehingga memberi kesan telanjang dan polos. Beberapa saat kepolosan itu dibiarkan, sampai melayang kain hijau panjang dari batten, yaitu tempat untuk menggantung lampu di proscenium stage (gambar 7). Diraihnya kain itu, lalu mulai dikenakan sebagai cawat dengan melilitkannya beberapa kali di antara selangkangan dan pinggangnya. Proses mengenakan cawat ini memunculkan disain tersendiri yang berasal dari kibasan kain panjang itu. Ketika cawat telah selesai dikenakan, lalu dilengkapi dengan property tari yang berupa topeng Hudoq Kita`.

Sebagaimana penari tunggal bercawat hijau, para penari kelompok juga hanya mengenakan $G$ string sebelum akhirnya mengenakan cawat hijau. Selain G String, para penari mengenakan topeng Hudoq Kublo, sebuah kreasi topeng yang berbentuk semacam topi panjang yang menutupi seluruh bagian kepala. Ada hiasan rumbai-rumbai kain berwarna-warni yang melingkar pada topi panjang itu, sehingga para penari tampak seperti menyunggi benda di kepalanya. Rumbai-rumbai ini terus bergoyang seiring dengan gerakan para penarinya yang dengan gesit bergerak dari satu motif ke motif berikutnya.

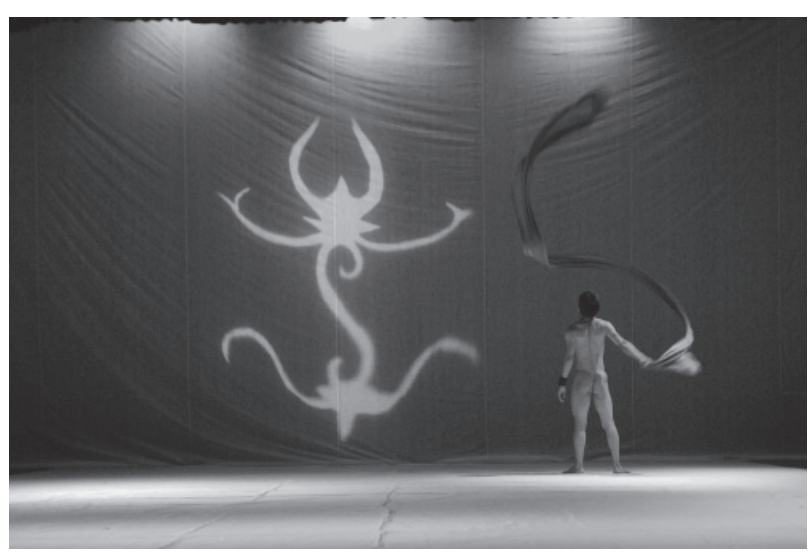

Gambar 7. Disain garis lanjutan yang terbentuk dari kibasan kain panjang (Foto: Maulana, 2013) 
Dengan mengenakan $G$ string dan topeng Hudoq Kublo, para penari masuk ke area pentas sambil menggigit sebagian dari kain hijau panjang. Bagian kain yang lain dipegang dan direntangkan sampai membentuk juntaian kain panjang, sebelum menjadi sebuah cawat. Gerak ke 7 penari kelompok itu sangat dinamis mengeksplorasi lembaran kain panjang itu. Kibasan-kibasan kain panjang itu membentuk disain garis lanjutan yang melayang di udara, kadang tampak seperti melesat dan menyambar. Ketika saatnya tiba, dengan caranya sendiri-sendiri kain itu dililitkan beberapa kali ke selangkangan dan pinggang, sampai tersisa ujung-ujung kain yang dibiarkan menjuntai menutupi separuh panjang pahanya. Jadilah mereka mengenakan cawat hijau dengan topeng Hudoq Kublo di atas kepalanya. Topeng ini akan diganti dengan topeng hudoq yang lain, yaitu Hudoq Kita', seperti yang dikenakan oleh penari tunggal. Dengan demikian penonton disuguhi proses mengenakan cawat 2 kali, yaitu oleh penari tunggal dan penari kelompok.

Tampaknya pemilihan menggunakan busana cawat itu adalah pilihan akan pernyataan diri penata tari. Cawat adalah busana yang biasanya dikenakan oleh laki-laki di suku-suku pedalaman, tidak saja di Indonesia tetapi di tempat-tempat lain di dunia masih ditemukan laki-laki mengenakan cawat sebagai pakaian sehari-hari dan pakaian adatnya. Bahan cawat bisa terbuat dari dedaunan, kulit kayu, atau sehelai kain. Di sebagian suku Dayak di pedalaman Kalimantan pun cawat masih menjadi pakaian yang melekat sebagai ciri identitas suku tersebut.

Tatag De Penyawo yang sesungguhnya merupakan hasil perenungan dan pencarian diri penata tari terhadap identitas sukunya dengan sengaja memilih cawat itu sebagai salah satu ciri identitas karyanya. Cawat di sini sebagai salah satu bentuk simbol yang diambilnya, untuk mewakili identitas suku dan leluhurnya. Di sisi lain, pilihan warna cawat hijau tua juga merupakan pertimbangan tersendiri. Dalam masyarakat tradisional, hijau sering dimengerti sebagai simbol kesuburan, gambaran masyarakat petani agraris yang hidup dari tanah pertanian. Lain halnya pilihan warna hijau dalam karya Tatag De Penyawo yang secara khusus ingin mengambil simbol warna yang identik dengan simbol agama tertentu.

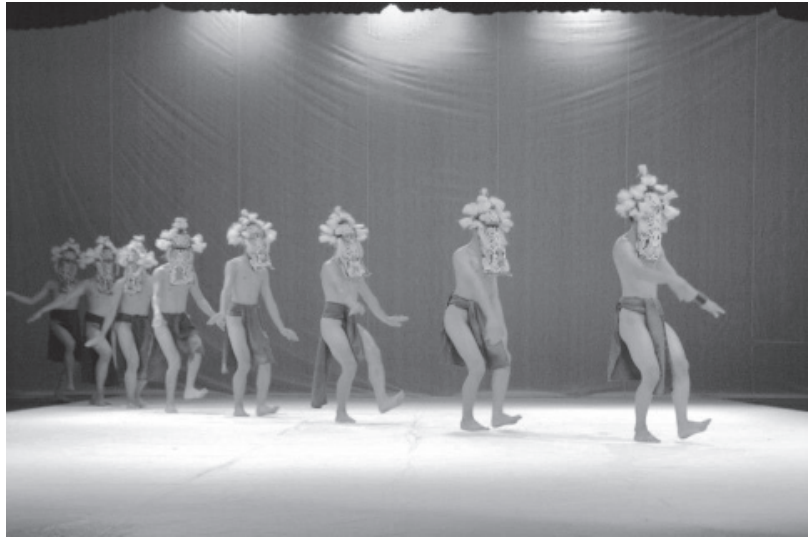

Gambar 8. Kostum yang sangat tipikal Dayak: Cawat dan topeng Hudoq Kita` (Foto: Maulana, 2013)

Kehadiran penari tunggal yang mengenakan $G$ string warna kulit menyiratkan bahwa manusia dilahirkan dalam kepolosan dan ketelanjangan, sehingga identitas yang melekat dalam tubuhnya adalah aliran darah warisan moyangnya. Ketelanjangan dan kepolosan ini sesungguhnya membebaskannya untuk dikenai atribut apapun, yang kelak atribut-atribut luar itu akan membentuk identitas baru. Itulah mengapa penari itu meraih kain yang turun dari atas. Ini sebuah simbol atribut yang datang dari "alam atas", alam yang memiliki kekuatan dan kekuasaan. Kain itu sebuah atribut luar, atau pembungkus. Jadi, manusia yang dilahirkan dalam ketelanjangan, kepolosan dan keterbukaannya, akan tertutupi oleh pembungkus yang berupa atribut-atribut bentukan sosial, budaya, dan religi. Kain hijau itulah bungkusnya, simbol religi yang datang dari dunia atas, untuk diraih dan kemudian dikenakan sebagai identitas baru untuknya. Namun demikian dalam identitas yang baru itu tetap melekat identitas lama, karena ia mengenakan dengan cara yang dikenal dalam tradisi lamanya, yakni cawat (gambar 8). Dari elemen rias, busana, dan property dalam karya Tatag De Penyawo dapat diketahui posisi dan sikap Usman dalam menghayati kehilangan identitasnya. Ia mengukuhkan posisinya sebagai orang Dayak yang muslim. Atribut topengtopeng itu sungguh merupakan penguatan akan pengambilan sikapnya ini.

\section{Tata Panggung dan Tata Cahaya}

Tata panggung dan tata cahaya menjadi unsur penting dalam penataan artistik karya "Tatag De Penyawo", karena kedua unsur tersebut saling 
mendukung dan berkaitan. Dalam karya ini tempat pertunjukan yang dipilih adalah panggung proscenium, yaitu panggung dengan bingkai untuk membatasi wilayah penonton dan pemain. Tata panggung yang digunakan pada karya ini pada dasarnya mengubah warna panggung proscenium yang biasanya berwarna hitam menjadi berwarna putih. Untuk itu digunakanlah cyclorama, side wings, dan lantai panggung yang semuanya berwarna putih. Cyclorama dibuat dari kain putih yang digantung di bagian belakang panggung, semua side wings dibalut dengan kain putih, sedangkan lantai panggung dilapisi dengan bahan semacam perlak plastik yang menyerupai vinil berwarna putih.

Keseluruhan ruang yang berwarna serba putih itu memberi kesan panggung tampak lebih luas. Pertimbangan lain dalam pemilihan warna panggung adalah kaitannya dengan pencahayaan, karena warna putih memiliki efek kuat dalam memantulkan cahaya warna apapun. Jadi, meskipun secara keseluruhan karya ini tidak menggunakan pencahayaan yang rumit dan kompleks, tetapi dengan menggunakan warna putih untuk seluruh bagian panggung, warnawarna yang digunakan dalam busana maupun property tampak lebih kuat. Celana pendek merah menjadi begitu menyala ketika mendapat sorotan lampu khusus di dalam panggung ini, demikian pula dengan kain panjang yang dikenakan sebagai cawat itu menjadi lebih tampak dramatis dalam ruangan yang serba putih yang disorot lampu khusus.

Unsur lain dalam tata panggung yang dimunculkan adalah gambar ornamen yang diproyeksikan di cyclorama dengan bantuan LCD projector. Gambar ornamen itu sangat khas Dayak, disebut Dewa Dange, yaitu gambaran manusia, symbol kebaikan. Motif seperti ini lazim digunakan oleh masyarakat Dayak untuk menghias dinding rumah panjang, rumah betang, lamin, perisai, serta topeng Hudoq. Kemunculan ornamen Dewa Dange dalam bentuk proyeksi ini semakin menguatkan nuansa Dayak dalam keseluruhan karya. Ornamen itu menjadi titik perhatian dari ruangan putih, yang mengingatkan akan hiasan serupa di tengah dinding rumah panjang suku Dayak.
Warna ruang pentas yang serba putih yang dipilih oleh penata tari, menyiratkan sebuah keadaan yang terbuka dan suci. Apa yang dilakukan di atas panggung putih itu merupakan simbol bahwa perenungan yang dilakukan Usman adalah sebuah kegiatan yang dilandasi niatan suci, untuk mengisi dunianya dengan laku religi yang dengan kesadarannya telah diambilnya, tetapi membiarkan degup aliran darah leluhurnya tetap mengalir dalam tubuhnya.

\section{Penutup}

Tatag De Penyawo adalah sebuah karya tari kontemporer dengan latar belakang etnis Suku Dayak di Kalimantan Timur. Karya ini merupakan ekspresi kegelisahan penata tarinya yang berada dalam keraguan identitas. Akankah dia menyebut dirinya suku Melayu karena ia muslim, ataukah menyebut Dayak karena darah yang mengalir di tubuhnya adalah tetesan leluhur yang mewariskan naluri kedayakan kepadanya.

Kebanyakan masyarakat Suku Dayak masih memegang teguh kepercayaan leluhur yang disebut Kaharingan. Meskipun telah memeluk agama - agama yang diakui pemerintah, mereka masih melestarikan tradisi adat Dayak, sebagai bentuk pewarisan tradisi dan penghormatan kepada leluhur. Akan tetapi ada salah satu sub suku Dayak, yaitu Tidung warganya memeluk agama Islam, dan tidak lagi menyebut sub suku itu adalah Dayak, tetapi menggolongkannya ke dalam rumpun suku Melayu. Tidung itu sendiri diturunkan dan masih berkerabat dengan Suku Dayak Murut. Hal inilah yang menggelisahkan penata tari, karena tampaknya ia ingin diakui sebagai orang Dayak yang muslim.

Kegelisahan itu kemudian direfleksikan ke dalam sebuah karya koreografi kelompok 9 penari laki-laki. Seluruh elemen koreografi yang meliputi gerak, ruang, iringan tari, rias - busana, pencahayaan, dan tata rupa pentas dijadikan media ungkap kegelisaham dengan mengolah materi-materi elemen tersebut.

Bagian-bagian dalam karya itu ditata secara apik untuk menyajikan penggalan dari bagian-bagian pengalaman hidup dan harapan-harapan yang ingin dicapainya. Rangkaian gerak yang sangat puitis di bagian pertama karya mengisahkan ketaatan 
pada tatanan keagamaan, sekaligus kenangan akan tradisi leluhur yang terus membekas dalam sanubarinya.

Seluruh elemen koreografi menyiratkan bagaimana ia mengambil posisi ketika berada pada dua situasi. Pengalaman ketubuhan, dan spiritualitasnya pada akhirnya menuntunnya untuk mendefinisikan ulang identitas dirinya. Meskipun penata tari ingin kembali pada aliran darah leluhurnya, akan tetapi ia ingin tetap mengenakan atribut baru yang menyejukkan dan yang telah menyadarkannya akan keberagaman manusia.

Walaupun Tatag De Penyawo merupakan karya tari yang membicarakan pengalaman dan kegelisahan seseorang, akan tetapi karya ini memuat nilai-nilai religiositas yang universal, yaitu kesadaran bahwa Tuhan telah menciptakan manusia dengan segala keberbedaannya. Meskipun manusia memiliki perbedaaan warna kulit, bangsa, bahasa, dan keyakinan, tetapi di dalam Tuhan kedudukan manusia adalah sama, yaitu sebagai umatNya yang sepatutnya menjalani hidup seturut dengan perintah dan jalan yang telah digariskanNya.

\section{Kepustakaan}

Cheney, Gay. 1989. Basic Concepts in Modern Dance, A Creative Approach. New Jersey: Princeton.

Coomans, Mikhail. 1987. Manusia Daya Dahulu, Sekarang, Masa Depan. Jakarta: PT. Gramedia.
Hadi, Sumandiyo. 2003. Aspek-aspek Dasar Koreografi Kelompok. Yogyakarta: Elkaphi.

Hawkins, Alma M. 2003. Bergerak Menurut Kata Hati. Terjemahan I Wayan Dibia. Jakarta: Masyarakat Seni Pertunjukan Indonesia.

Indrahastuti, Tri, 2012. Hudoq Kita' Seni Pertunjukan Ritual di Desa Pampang Kalimanta Timur (tesis). Yogyakarta: PPS ISI Yogyakarta.

Maulana, Najrid Usman. 2013. Tatag De Penyawo (skripsi). Yogyakarta: Jurusan Tari ISI Yogyakarta.

Maunati, Yekti. 2006. Identitas Dayak. Yogyakarta: LkiS.

Radam, Noerid Haloei. 2001. Religi Orang Bukit. Yogyakarta: Yayasan Semesta.

Sarjiwo, 2011. "Rim-ba: Karya Tari Hasil Refleksi Kehidupan Suku Anak Dalam" dalam Resital Jurnal Seni Pertunjukan, Volume 12 No. 2 Desember 2011.

Smith, Jacqueline. 1976. Dance Composition; A Practical Guide for Teachers (Komposisi Tari; Sebuah Petunjuk Praktis Bagi Guru). Terjemahan Ben Suharto. Yogyakarta: Ikalasti.

\section{Video}

Maulana, Najrid Usman. 2013. Tatag De Penyawo. (DVD), Koleksi pribadi.

PSN. 2005. Tari Komunal (DVD). 